\title{
THE TRANSFORMATIVE POTENTIAL OF CREATIVE ART PRACTICES IN THE CONTEXT OF INTERDISCIPLINARY RESEARCH
}

\author{
Kyong-Mi PAEK \\ Ulsan National Institute of Science and Technology, Division of General Studies 50 UNIST-gil, \\ Ulsan 44919, South Korea
}

Received 23 March 2019; accepted 17 May 2019

\begin{abstract}
A growing body of literature addressing the need for educational innovations has also stressed the value of interdisciplinary approaches that incorporate art into teaching and learning. This paper aims to extend educators' understanding of art-science interactions by presenting an empirical study that explores a unique art residency program created on the campus of a university that specializes in science and technology. The study reviews the art practices of three contemporary artists who participated in a program developed in conjunction with an interdisciplinary research project seeking ways to build an ecologically sustainable community and operated by a renewable energy resource-based economic system. Data that include observations, artist talks, and in-person interviews were collected from multiple sources during the residency to understand the distinguished processes involved in the development of individual art projects. A follow-up cross-case analysis revealed a few notable characteristics: connecting art with life through waste recycling, process-oriented practices highlighting resource circulation, and creating value using bricolage strategies. Regarding educational implications, discussions centered upon the potential transformational space identified from the creative art practices in the context of interdisciplinary research.
\end{abstract}

Keywords: art residency, contemporary artists, creative practice, educational innovations, transformational space.

\section{Introduction}

The growing body of literature addressing the need for educational innovations has also stressed the value of interdisciplinary approaches that incorporate art into teaching and learning (Lee, Fillis, \& Lehman, 2018; Curtis, Reid, \& Ballard, 2012; Hudson, 2001; Jacobson, Seavey, \& Mueller, 2016; Steelman et al., 2018). Grounded on the idea that different perspectives and ways of understanding the world can lead to more holistic and creative approaches, Susan K. Jacobson, Jennifer R. Seavey, and Robert C. Mueller (2016) discussed ways of integrating science and art education to kick-start creative communication about climate

*Corresponding author. E-mail: kpaek@unist.ac.kr

This is an Open Access article distributed under the terms of the Creative Commons Attribution License (http://creativecommons. org/licenses/by/4.0/), which permits unrestricted use, distribution, and reproduction in any medium, provided the original author and source are credited. 
change. Toddi A. Steelman, Evan Andrews, Sarah Baines, Lalita Bharadwaj, Emilie Rose Bjornson, Lori Bradford, Kendrick Cardinal, Gary Carriere, Jennifer Fresque-Baxter, Timothy D. Jardine, Ingrid MacColl, Stuart Macmillan, Jocelyn Marten, Carla Orosz, Maureen G. Reed, Iain Rose, Karon Shmon, Susan Shantz, Kiri Staples, Graham Strickert and Morgan Voyageur pointed out that the long-standing tendency of modern science, in its attempt to separate objective experiences from subjective ones, limits "what is knowable to primarily that which can be objectively verified, thereby depleting and invalidating other more subjective lived experiences and impoverishing our ability to fully express what is important in our lives" (2018). They suggested that art is one avenue for bridging different ways of knowing and that it holds potential for creating boundary objects that create multiple meanings and interpretations for diverse cultural groups. Such an accessible nature has enabled art to play a "role in communicating issues, influencing and educating people, and challenging dominant paradigms" (Curtis et al., 2012, p. 3). In science education, to overcome the limitations of science-based understanding and technocentric teaching approaches and to encourage more creative practices, many researchers have discussed the potential for art to engage people in reflecting upon their values or behaviors and to offer "opportunities for integrating new awareness or different perspectives into the development of new and more effective solutions" (Gray \& Thomson, 2016; Jacobson et al., 2016, p. 30). Despite the recognition of its potential, empirical examples of this remain rare (Steelman et al., 2018). This paper aims to extend educators' understandings of interdisciplinary practices by presenting an empirical study that explores a unique art residency program created on the campus of a university that specializes in science and technology.

\section{Study context}

The residency program was organized in conjunction with Science Walden, an interdisciplinary research project aimed at building an ecologically sustainable community operated by a renewable energy resource-based economic system (Cho, 2017a, 2017b). Since 2015, research in Science Walden has been developed through two major interrelated directions. The first of these is the development of a resource recirculation system. This involves replacing traditional flushing toilets with non-flushing toilet systems, offering a considerable reduction in water consumption and the effective accumulation of human excretion to be used as resources for producing biogas. The other direction taken by research in Science Walden is the development of an economic system based on renewable energy obtained through non-flushing toilets. In the community based on this economic system, all inhabitants earn a basic income by having their excretion processed into various energies, including methane and biodiesel, through means of non-flushing toilet systems (Paek, 2019). A two-story residential building and laboratory space called Science Cabin was built to execute tests on the ecological circulation of this renewable energy system (see Table 1).

The inner structure consisted of two interconnected main spaces - a residential space and a laboratory - designed for efficient energy circulation: excretions collected through non-flushing toilets in the residential space are sent to underground storage then delivered to the anaerobic digesters in the adjoining laboratory. The biogas produced in the lab is sent back to the living space for cooking and to provide hot water. 
Table 1. Science Cabin, the building used as an art residency (source: courtesy of Science Walden)

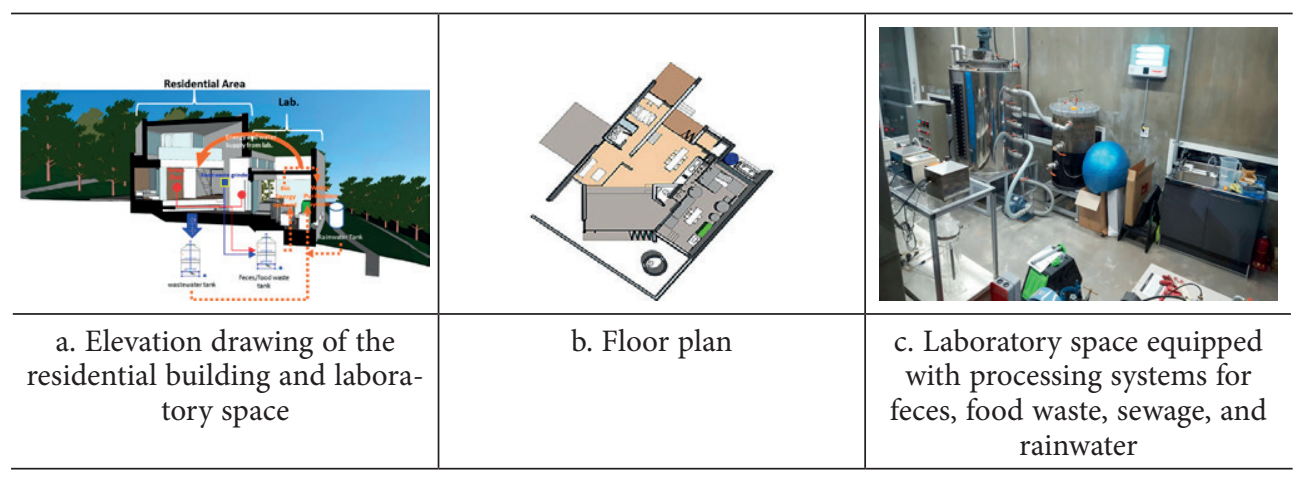

While the primary purpose of this building was initially to test its energy circulation system, it has also functioned as a multipurpose space to promote diverse interdisciplinary activities. An art residency program was created in this space under the expectation that it would play a role in broadening the vision of the Science Walden research project and stimulating creative and innovative research ideas and practices. Two artists stayed in November 2018, and another group of three artists resided there in January 2019, each of them for a duration of one month. During the four weeks of their residency, the artists were allowed to use the entire residential space. In addition to minimizing unexpected interruptions by visitors, weekly internal meetings were arranged to promote communication and interactions with other science- and engineering-based researchers and the students participating in the research projects.

The review section of this paper focuses on the practices of three (Won-gil Jeon, Seung-Kyun Lim and Soonim Kim) of the five artists who completed their residencies. The primary study interest was to examine how individual artists integrate the concept of the ecological living system envisioned by the Science Walden research project. The questions posed to guide this empirical study were: "What kinds of characteristics and potentials can be found in the practices of artists in the context of interdisciplinary research?" and "What implications do these findings provide for educational innovations?".

\section{Data collection and analysis}

Data was collected during the residencies through multiple sources, including observations, artist talks, and in-person interviews. Due to my position as an insider involved in the design and operation of the residency program, I was able to observe and take pictures of the ongoing works of the artists at least once per week. Verbal presentations given by the artists about their own practices and visitors' responses occurred during the artist talks, which were arranged as weekly events that usually lasted for an hour each. Also, the artists' views on their work experiences in the building as well as their living experiences on campus were collected through 30-50-minute-long in-person interviews conducted at the entry and exit points of the Science Cabin. All verbal data were audiotaped, transcribed, and arranged according to 
time, followed by cross-checks of the transcripts with pictures and video images taken at intervals of about one week each.

Based on several peculiarities drawn out from an initial review of the diverse practices of individual artists, this paper presents a particularly distinguished process involved in the development of the individual practices of the three studied artists. Next, the paper presents a few notable characteristics of residency art practices identified through a follow-up contextual analysis. Regarding educational implications, discussions centered upon the potential transformational space identified from the creative art practices in the context of interdisciplinary research.

\section{The distinguished processes involved in the practices of the three artists}

Each of the artists developed their projects in a distinguished way, bringing their previous experiences and incorporating their new experiences from living in the space into the processes and content of their works.

\subsection{Won-gil Jeon's practice}

Jeon (b. 1960) has been working with nature since the mid-1980s. In particular, he is interested in communing with nature, allowing it to become part of his works (see Table 2).

Having been interested in physiological processes such as ingestion, digestion, and excretion, Jeon sought ways to use excretions in his residency work. Prior to his residency, however, Jeon had to deal with deodorization as a major issue that arose due to the creation of this type of artwork. He used many methods in his attempts to lessen the unpleasant odors, including ripening, burning, drying, and mixing the excretions with ashes and coffee powder. Jeon began his residency at Science Cabin by setting up a work system which composed of a handmade chair through which Jeon could gather his own feces, a tin pail in which to burn the feces, filters to drain the mixtures of powdered feces and coffee powder, and a large table covered with white paper (Table 3a). Using this system, Jeon initiated stain painting by putting a spoonful of powered excretion into coffee filters and pouring water into the filters several times per day. The water passing through the filters produced stains on the table.

Table 2. Several of Won-gil Jeon's previous works (source: courtesy of Won-gil Jeon)

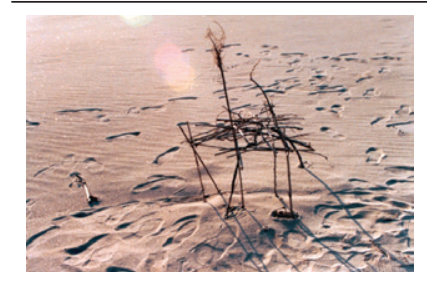

a. A house on sand, 1990

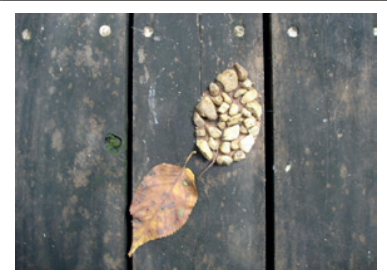

b. Leaves and stones, 2004

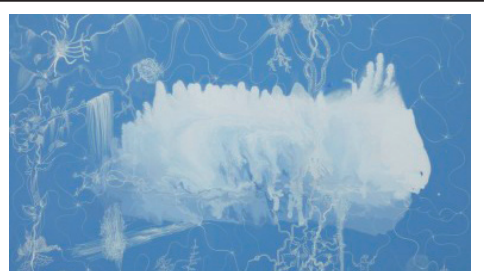

c. Eternal landscape-pond, 2012 
These stains became larger every day and eventually led to the table resembling a painting (Table 3b). At his first meeting with the researchers, Jeon defined his work as "art operating in his life", stating:

\begin{abstract}
"The stains are naturally formed by the feces passing through the filters as if they had just come out of the digestive organ. Such strains are not aesthetically controlled by me, just as we cannot control our digestive processes $\langle\ldots$. . The processes of this work, pouring the coffee I drink and putting my feces into these filters, are really connected to my life. This is an occasion for me to experiment with "live" art operating in my life" (Jeon \& Paek, 2018).
\end{abstract}

Over time, the colors of the stains became deeper and their textures grew thicker, making their shapes even more interesting (Table 3c). At a meeting with a group of engineering students, Jeon shared his idea of challenging the perceptions of viewers by making them reconsider the conventional value of feces and gold. He noted that he had thought about several possible ways of translating the idea into his stain painting practice. Then, on the spot, Jeon made an impromptu offer by informing the students that he had put his feces powder in only one of the five filters on the table and asking them to guess which filter he had used to do this. As a few students carefully marked different stains, Jeon attached small pieces of gold to these stains. Later, with satisfaction, he shared the following idea.

"While discussing the idea with students, the idea of considering the contrasting value of feces and gold has developed into an enjoyable collaborative activity. A question of "truth" emerged while developing this project. I will not tell you which of the five filters here I put my feces into. Without knowing the truth, it could be here or there. So far, four gold pieces have been placed onto the stains. The stain with the greatest number of gold pieces might be the answer. Perhaps what is considered true looks true just because many of us believe that it is. But, in fact, the truth could be in other places" (Jeon, 2018).

At the open studio arranged on the last day of his residency, Jeon declared that he would continue with the stain painting. He valued his residency as a special time that had enabled him to initiate his lifetime project of developing live art in his life.

Table 3. Won-gil Jeon's works developed during his residency (source: courtesy of Won-gil Jeon)

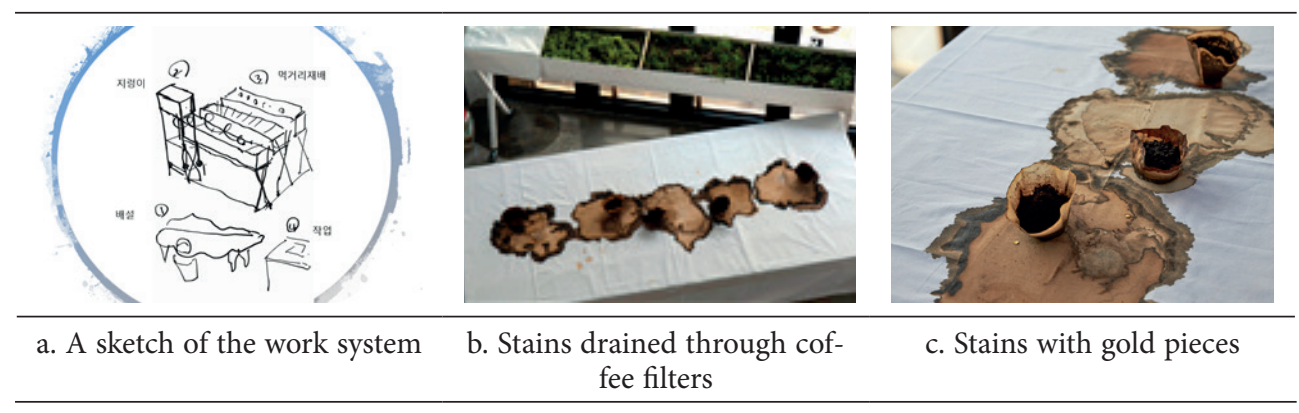




\subsection{Seung-Kyun Lim's practice}

Lim (b. 1984) is a young artist with four years of experience. In 2017, a museum in Deajeon, a large city in the west of South Korea, commissioned Lim to conduct an art project that examined the local environment of Deajeon. Knowing that Deajeon was the city in which the largest number of civilians were killed during the Korean War in the 1950s, Lim created many works using soil and water collected from several sites at which the massacre had occurred (Table 4). As shown in his project work, Lim intentionally adopted scientific methods to collect, test, and analyze the materials and to record and present the outcomes of the project. Lim mentioned that he applied for this residency due to its unfamiliar nature of the science centered campus environment. As an artist living in the scientific community, he wanted the chance to develop his methodologies through making art.

For his residency work, Lim was interested in exploring ways of processing sludge and fecal residue through a bioenergy production system. At his first meeting at Science Cabin, Lim outlined his idea of developing incense using sludge discharged from Science Cabin's laboratory space. For technical support, I arranged a meeting with a knowledgeable researcher who could provide Lim with a detailed overview of the bioenergy system that operated in the laboratory. Lim asked for a data analysis sheet that compared the incenses of excrement collected from different sources. This meeting was followed by a visit to another more specialized biogas laboratory. After obtaining basic technological information, Lim began his sludge-based incense project by collecting not only sludge from human feces but also excrement from dogs and birds. He also chose other materials, such as the bark and leaves of trees, to be added in the process of formulating a range of incenses (Table 5a). During the first two weeks of his work, along with collecting materials, Lim focused on gathering cultural and technical information on diverse methods of making incense and testing flavors by combining different sets, colors, and shapes of ingredients (Table 5b). At the final open studio, after showing his materials and tools to visitors, he explained the process he used as follows:

"I conducted research on the process of making incense and the things that could be added. I tried to collect and grind the bark of old trees and mix it with the sludge obtained from the lab $\langle\ldots\rangle$ and added other natural materials found around here too... It was hard to identify the right amounts of things to be mixed together and the right density of the paste mixtures. When they get too dense, the mixtures become tough and wouldn't dry easily $\langle\ldots\rangle$. Rolling by hand like this is said to be a method widely

Table 4. Several of Seung-Kyun Lim's previous works (source: courtesy of Seung-Kyun Lim)

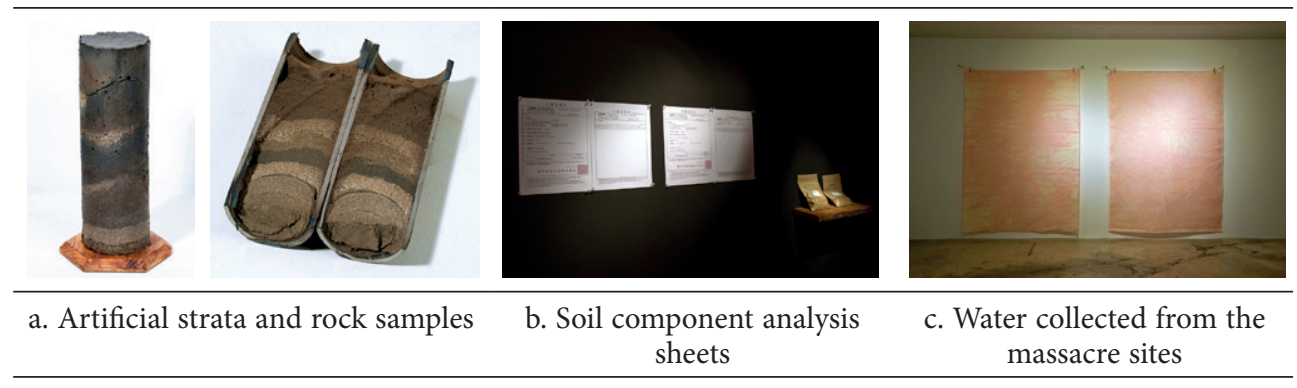


Table 5. Lim's works developed during his residency (source: created by author)

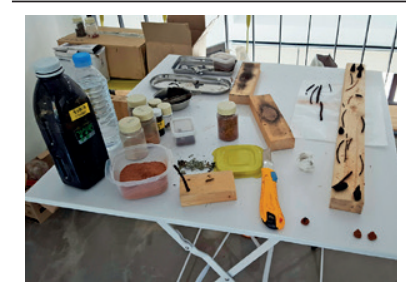

a. Ingredients collected to formulate a range of incenses

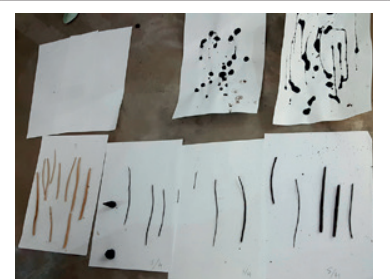

b. Experiments on the colors and shapes of incense

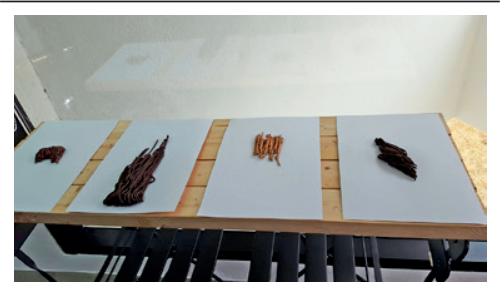

c. The paste mixtures came out through a noodle squeezer

used in India. Because it is made by hand, the shapes become irregular, and some of them bend and twist when they become dry" (Lim, 2018).

Then, Lim displayed a few dried paste mixtures as derivative works (Table 5c), which had been made from careful material explorations involved in his paste-mixing work. Lim shared the moment when this new idea emerged as follows:

"[Pointing to the images in Table 5b] These are some of the images that arose while working with some of the paste mixtures. The straight noodle stripes were made by pushing the paste mixtures down through a spaghetti noodle squeezer, and I saw the pastes begin to take unusual shapes as they wound, bended and lost moisture. I found them so interesting. Realizing that they could be appreciated as aesthetic incenses, I collected some of them and set them in frames" (2018).

The final outcomes of Lim's one-month residency work were twofold: one was a neatly finished piece of incense placed in a gift box as an item for sale (Table $6 a, 6 b$ ), and the other was pieces of art set in a frame as an aesthetic object (Table 6c).

\subsection{Soonim Kim's practice}

Kim (b. 1975) introduced herself as an artist who learns from local environments, creates works using local materials, and enjoys meeting local people. With interest in what she eats every day, every time she consumed grapes, she pasted the skin remains into a notebook as one writes a diary (Table 7a). The Growth Story of Home+Farm 2017-2018 (Table 7b, 7c) is

Table 6. The final outcomes of Lim's work (source: courtesy of Seung-Kyun Lim)

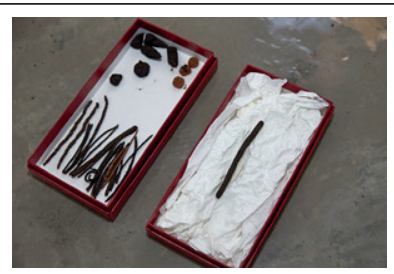

a. Different shapes of incense

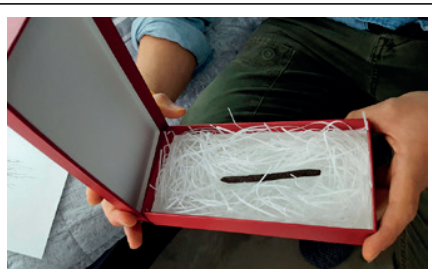

b. Incense placed in a gift box

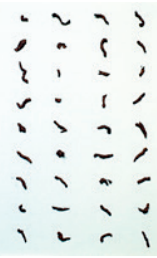

c. Paste stripes in a frame 
Table 7. Several of Soonim Kim's previous works (source: courtesy of Soonim Kim)

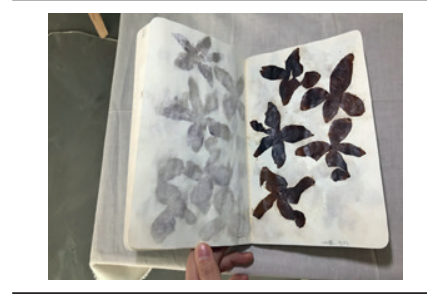

a. Reading Grapes, 2017

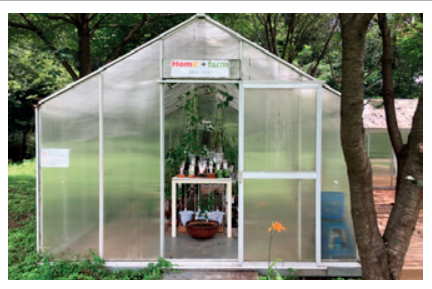

b. Home+Farm 2017-2018

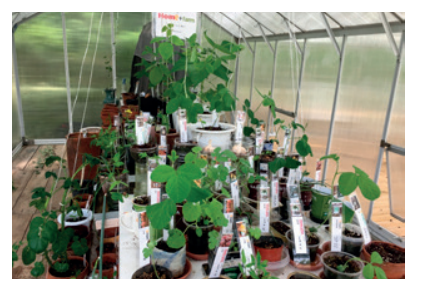

c. Home + Farm 2017-2018, in detail

another of her recent projects that reflects her interest in life and food. The project involved planting roots and seeds that were left after the main parts of vegetables and fruits bought at markets were consumed. Then, she filmed these remains to determine how they put forth buds, sprouted leaves, and bore fruits again. At her first interview, Kim said that she was attracted to the main function of Science Cabin as a living laboratory operated by its unique renewable resource system. She valued the on-site experience, looking for challenges and possibilities that could emerged during her time spent living in an unfamiliar space in a science community.

Having been aware of Science Cabin as a place where waste becomes a source of energy, Kim found its connection to what she had done and continued to do in her work: creating works by pasting the remains of food on paper. She used the remains of food that she consumed every day, including seeds, fruit skins, and leaves left after brewing tea (Table 8). Kim focused on this practice for the first two weeks of her residency. This involved careful observations of the natural processes of changes in diverse food remains' physical properties. Also, it required many experiments to be conducted on the remains, including boiling, drying, dissevering, spreading, and stretching them to use them as artistic materials. Kim described the time-consuming work as follows:

"One has to look at it while letting it dry <...> [to see] what it looks like. Tea leaves too. They look different from their original shape when they were parts of a tree. I eat things slowly to look at the details $\langle\ldots\rangle$ then, instead of throwing them away, I put them on a large piece of paper and leave them there $\langle\ldots\rangle$ then they begin affecting the paper, making it twisted or wrinkled. Tea leaves make visible stains on paper. Each stain reminded me of what I drank, how strong the drink was, or with whom I had the tea. Time is piled up in the stain" (Kim, 2019).

Kim's perseverant practice of revealing the physical properties of the energy remaining in food wastes indicated her interest in bringing to our attention the unrecognized value of daily waste. As her residency went into its third week, Kim's earlier practice developed into large-scale painting. Kim acknowledged that the idea arose from her laboratory experience during the first week of her residency. She had the opportunity to visit a laboratory specializing in biogas research with two other residency artists. At the open studio, Kim shared what she heard in the lab and how the story inspired her to be aware of invisible microorganisms, and the following statement indicated that this eventually helped her to extend the scope of her works further: 
Table 8. Soonim Kim's works using remains of food (source: created by author)

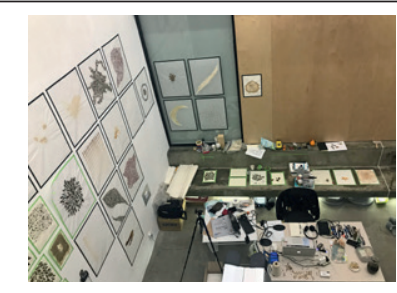

a. Drawings with remains of food

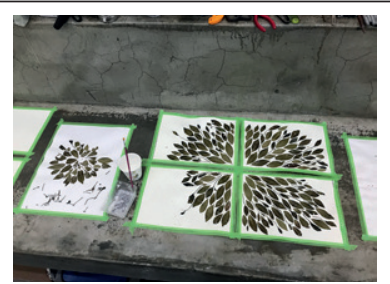

b. Drawings with tea leaves

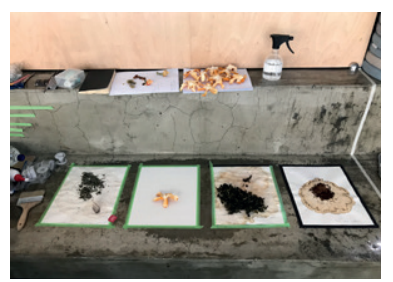

c. Drawings with stains of tea leaves

"I came to know there are round ones, elongated ones, chubby ones, thin and small ones, and furry ones. They can make sounds and communicate, exchanging electronic signals between each other, and I thought they were so cute. Although we are not able to see them, they exist, move, and communicate, and such activities affect our lives $\langle\ldots\rangle$. Imagining the activities of invisible living things made me so excited, and my impression was like that at that time I heard the story. Later, a thought crossed my mind. I thought "this seems to be similar to what people do". Although [they are] different sizes, they in fact live very much like how we live. We also talk to each other, communicate, and make noise. So, I began to look at what the three of us do in our everyday lives in Science Cabin" (2019).

After finding that each artist living in Science Cabin had different food preferences and ate different things, Kim also noticed that sharing the space often made them share their foods. This food sharing among the residency artists made Kim feel as though their communication was similar to what microorganisms do to communicate: exchanging electronic signals between one another. To represent this feeling visually, Kim initiated a new project called "Dancing Microorganisms" (Table 9):

"Usually, we throw food remains away without taking a second look. But here in Science Cabin, food wastes become a source of energy. $\langle\ldots\rangle$ As each one of us has unique tastes, we prepare different things to eat; however, cohabitation makes us share our foods like microorganisms exchange signals with each other to communicate. To express our relationships, I used food wastes as symbolic materials that represented our energy to communicate" (2019).

Table 9. "Dancing Microorganisms" (source: created by author)
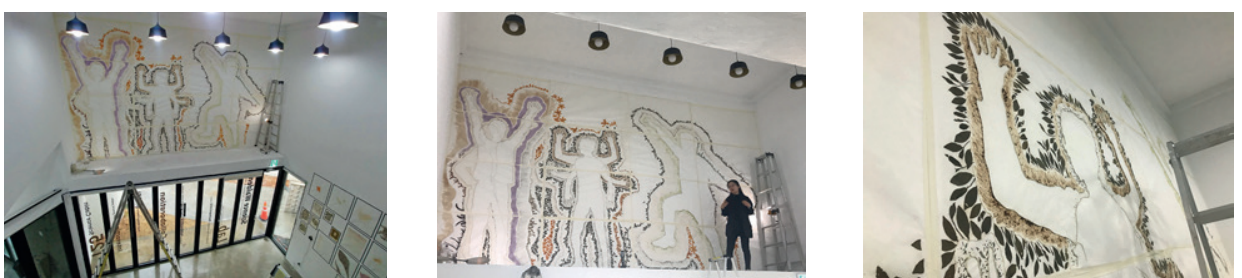
"Dancing Microorganisms" extended Kim's perseverant efforts to revealing the physical properties of the energy that remains in food wastes and to the fact that these wastes are a valuable source of energy for encouraging communications and building relationships.

\section{Characteristics found in the practices of the artists}

Certainly, one month assigned to the residency was not enough to expect visible outcomes. Nevertheless, the incoming artists appeared to be considerably motivated by the unusual occasion of stepping into a space created by an on-campus science and technology research community. Several patterns were observed in the practices of the artists during their residencies. Their practices for the first two weeks progressed slowly and looked more like explorations. Then, as they got into the third week of their residencies, more intensive efforts, interesting extensions, and transformations were observed in the practices of the artists. These changes illuminated both the expectations and the awareness that the artists brought to their residency works. The artists intentionally put their efforts towards open-mindedness and, at the same time, being aware of their checkout times. Each took a distinguished approach to the concept of the renewable energy system that the research project was aimed to develop. A cross-case review of their practices revealed a few notable characteristics: connecting art with life through waste recycling, process-oriented practices highlighting resource circulation, and creating value using bricolage strategies.

\subsection{Connecting art with life through waste recycling}

Science Cabin is a living laboratory designed to connect residential space with a bioenergy production system. Using non-flushing toilets, gas stoves, and hot water heating directly connected to energy production facilities in the adjoining laboratory every day, the artists found themselves situated right at the center of renewable energy circulation, acting as both suppliers and consumers of the resources circulating within the building. Under these ecological living conditions, each artist took a distinguished approach to the concept of renewable energy systems by connecting art with life through recycling waste. Jeon's work demonstrated his efforts to translate the scientific process of human bowel movements with the renewable energy system operating in the laboratory into a form of stain painting created through coffee filters linked to the physiological action operating in his body. Lim's incense work, which presented itself in both commercial and aesthetic forms, led to the possibility of determining and increasing the value of sludge - through the residue of feces. Kim's work disclosed and increased the hidden value of daily food wastes by highlighting them as sources of energy for encouraging communication and building relationships. These practices of connecting art with life through recycling waste can be considered creative endeavors that raise awareness of our relationships with what has largely been undervalued. Such efforts, in fact, are linked to what can be found in the practice of contemporary art: the desire to abolish the distance separating art from life by linking art to the concrete areas of life and everyday experiences (Kim, 1998). It is possible to see that the consciousness of one's position as a dual role mediator (both a supplier and a consumer of energy) in the resource circulation system 
operating in Science Cabin may have affected the practices of these artists in making them become life-centered.

\subsection{Process-oriented practices that highlight resource circulation}

In connecting with Science Cabin's resource circulation system, the artists presented intriguing process-oriented practices of creating value out of what is carelessly discharged from our bodies and discarded from our daily lives. Jeon's painting grew with the interminable layers of stains spread over the paper and with Jeon having had his own feces passed through a number of coffee filters. Likewise, an intentional time-consuming process was observed in Kim's practice of filming a drying out orange's skin and observing paper reacting to some tea leaves placed on it as well as in Lim's extensive explorations on diverse ways of extracting incense out of sludge. As they intended to show the passage of time into which observable physical changes were built using fragile or volatile materials and natural processes, these practices can be characterized as process art (Baik, 2010). According to Jean Robertson and Craig McDaniel, the term process art "was first used in the late 1960s to refer to art made from mutable materials, such as $\langle\ldots\rangle$, plants, felt, latex, ice, and water, whose form was a result of natural processes or forces" (2017, p. 159). Contemporary artists continue to explore creative possibilities by working with short-lasting materials and natural processes, emphasizing the "process" of making art. This methodological tradition was employed by the artists in residency to increase the flexibility of their explorations and the responsiveness to the possibilities that emerged from their onsite field experiences during their residencies.

\subsection{Creating value using "bricolage" strategies}

Art practices in residency are distinguished by the process of exploring the potential value of wastes that are unconsciously discharged and discarded every day. In the creative strategies of exploring the potential value of wastes employed by artists through stain paintings containing the artist's own feces, incenses made of sludge, and paintings made of food waste, rubbish was re-illuminated as a source of energy for building relationships and communication. Shaping the meaningful and useful out of the wastes made by human life is one of the strategies of bricolage. This term, which is French in origin, means "the do-it-yourself process of constructing objects from odds and ends" (Dezeuze, 2008, p. 31). In an art context, it refers to "the construction or creation of an artwork from any materials that come to hand" (Tate, 2019), and French social anthropologist Claude Lévi-Strauss viewed the bricoleuer as "someone who works with his hands and uses devious means compared to those of a craftsman" (1962, p. 16-17). The bricoleuer is adept at conducting a wide range of tasks, "but, unlike an engineer, he does not depend upon the availability of raw materials and tools conceived and procured for the purpose of the project" (Lévi-Strauss, 1962, p. 17). Due to its spontaneous nature, instead of scientific and structured thinking, bricolage demands challenging and imaginative minds that enable people to act according to limited circumstances and solve problems through prompt responses. In the same vein, Sae-Mi Cho (2017) defines bricolage as both an instant creative effort to determine the maximum value of what is given using available 
resources and the capability to create new meanings by looking at things from different angles and combining different things together instantly. As it suggests the changing of viewpoints guided by inquiring minds that keep a wary eye on the familiar, today, the meaning of bricolage has been extended to the qualifications expected of contemporary people living in an era of uncertainty and complexity (Cho, S.-M. 2017). The studio practice of residency artists in the interdisciplinary research context reviewed here suggests that quality of mind developed through the creative strategies of bricolage can be a useful tool when considering the development of creative ideas and practices across diverse fields.

\section{The transformative potential of art practice}

The diverse processes of artistic exploration observed in Science Cabin suggest that the art residency plays a role in transforming the space into "a border zone or transition, where creative energy gives shape to what is beyond worlds", which "creates space for intuitive knowledge in that it dispenses with conceptual categories, reasoning, and the separation of subject and object" (Steelman et al., 2018). According to Steelman and colleagues (2018), such space has the quality of what Basarab Nicolescu (2010) recognizes as the "hidden third", which allows for a more holistic human experience, one that creates "opportunity for bringing together both the subjective and objective within a larger umbrella of meaning". In this view, art - as it holds the potential for multiple meanings and interpretations for diverse audiences - becomes an avenue through which to bring together different ways of knowing, helping scientists to move away from their own scientific traditions in approaching problems (Jacobson et al., 2016). One of the engineering students, Yoon Joung Kwak, who regularly observed the art practice of resident artists, points out the similarities and differences in the development of individual art projects. She states,

\footnotetext{
"It was the first time that I saw art-making activities up close. The artists' practice looked quite similar to what science researchers do. The method and processes of art practice, such as conducting experiments with materials or recording images, looked very much like those of laboratory practice $\langle\ldots\rangle$ What was interesting was the tendency of artists to think outside the box in their practice. I was surprised when I heard that Kim wanted to use a space two stories high (see Table $9-$ K.-M. P.) because it wouldn't be what people would normally think of. The fact that she initiated a large painting in such a narrow space demonstrated artists' challenging spirit. It is like a strong will to do what one likes to do" (Kwak \& Paek, 2019).
}

This student's response, in that it reflects the transformative potential of art practice to extend scientific perspectives, has educational implications. The artistic explorations reviewed in this paper indicate that the residency holds the potential to become a third space, or a zone of development, for enhancing learning (Gutiérrez, Baquedano-López, \& Tejeda, 1999). The third space theory introduced by Homi K. Bhabha (1994) refers to "a co-created space where individuals have the opportunity to take ownership of their learning by engaging in discussions and participating in cultural practices" (Timm-Bottos \& Reilly, 2015, p. 103). At least to some degree, the art residency program is filled with diverse artistic explorations that are playful, transformative, multidirectional, and discursive, allowing the living laboratory to be a transformative space that facilitates and fosters creative interactions and 
learning. However, despite several notable impacts of social interactions observed in Jeon's idea of attaching gold pieces to the stain developed during his meeting with student visitors and Kim's response to the researcher's microorganism story, the scope of the data collected in this study is far too limited to extend discussions. This is due to the restricted times for meeting with visitors, which was necessary to secure hours of studio work during a relatively short residency. Consequently, the transformative potential of the art residency operating in the context of interdisciplinary research discussed in this study is mostly based on data collected from the artists themselves. Further studies on hybridity and diversity, developed through more challenging and extensive social interactions in the residency space, would add to the discussion of third spaces, complex environments that hold transformative potential for change and that could expand the scope of what we learn (Gutiérrez et al., 1999; Timm-Bottos \& Reilly, 2015).

\section{Conclusions}

In the context of the Science Walden research project, the art residency was created to promote diverse interdisciplinary activities, broaden the vision of the research project, and stimulate creative and innovative research ideas and practices. This study identifies idiosyncratic processes in the development of individual art projects and their notable characteristics, suggesting the art residency's transformative potential in generating the creative energy with which to extend scientific perspectives and develop more comprehensive ways of knowing. The findings of this empirical study contribute to educators' understanding of art-science interactions and their value in promoting dynamics that facilitate more creative learning communities.

\section{Funding}

This work was supported by the National Research Foundation of Korea Grant funded by the Government of South Korea (Ministry of Science, ICT and Future Planning) (No. NRF2015R1A5A7037825).

\section{References}

Baik, Y. (2010). Formative strategy and methodology of process art. Journal of Basic Design and Art, 11(3), 197-205.

Bhabha, H. K. (1994). The location of culture. London and New York: Routledge.

Cho, J. (2017a). Feces Standard Money (FSM). Edge. Retrieved from https://www.edge.org/response-detail/26660

Cho, J. (2017b). Philosophy of convergence research: "Science Walden", convergence research project of science and art. Convergence Research Review, 3(6), 33-64.

Cho, S.-M. (2017). Craft as a process and practice: bricolage as framework related to expansion of craft. The Journal of Aesthetics and Science of Art, 51, 336-367. https://doi.org/10.17527/JASA.51.0.11

Curtis, D. J., Reid, N., \& Ballard, G. (2012). Communicating ecology through art: what scientists think. Ecology and Society, 17(2). Retrieved from https://www.ecologyandsociety.org/vol17/iss2/art3/ 
Dezeuze, A. (2008). Assemblage, bricolage, and the practice of everyday life. Art Journal, 67(1), 31-37. https://doi.org/10.1080/00043249.2008.10791292

Gray, T., \& Thomson, C. (2016). Transforming environmental awareness of students through the arts and place-based pedagogies. Learning Landscapes, 9(2), 239-260.

Gutiérrez, K. D., Baquedano-López, P., \& Tejeda, C. (1999). Rethinking diversity: hybridity and hybrid language practices in the third space. Mind, Culture, and Activity, 6(4), 286-303. https://doi.org/10.1080/10749039909524733

Hudson, S. J. (2001). Challenges for environmental education: issues and ideas for the 21st century. Environmental education, a vital component of efforts to solve environmental problems, must stay relevant to the needs and interests of the community and yet constantly adapt to the rapidly changing social and technological landscape. BioScience, 51(4), 283-288. https://doi.org/10.1641/0006-3568(2001)051[0283:CFEEIA]2.0.CO;2

Jacobson, S. K., Seavey, J. R., \& Mueller, R. C. (2016). Integrated science and art education for creative climate change communication. Ecology and Society, 21(3). Retrieved from https://www.ecologyandsociety.org/vol21/iss3/art30/

Jeon, W.-G., \& Paek, K.-M. (2018). Personal interview [unpublished source].

Jeon, W.-G. (2018). Public talk for a society [unpublished source].

Kim, A. (1998). Soo-Ja Kim: a solitary performance with old fabric. Retrieved from http://www.kimsooja. com/texts/airyung.html

Kim, S. (2019). Public talk for a society [unpublished source].

Kwak, Y.-J., \& Paek, K.-M. (2019). Personal interview [unpublished source].

Lee, B., Fillis, I., \& Lehman, K. (2018). Art, science and organizational interactions: exploring the value of artist residencies on campus. Journal of Business Research, 85, 444-451. https://doi.org/10.1016/j.jbusres.2017.10.022

Lévi-Strauss, C. (1962). The savage mind. London: Weidenfeld and Nicolson.

Lim, S.-K. (2018). Public talk for a society [unpublished source].

Nicolescu, B. (2010). Methodology of transdisciplinarity - levels of reality. Logic of the included middle and complexity. Transdisciplinary Journal of Engineering and Science, 1, 17-32. https://doi.org/10.22545/2010/0009

Paek, K. (2019). Artists' creative contributions in the context of interdisciplinary research. Creativity Studies, 12(1). 131-145. Retrieved from https://journals.vgtu.lt/index.php/CS/article/view/9141

Robertson, J., \& McDaniel, C. (2017). Themes of contemporary art: visual art after 1980. Oxford: Oxford University Press.

Steelman, T. A., Andrews, E., Baines, S., Bharadwaj, L., Bjornson, E. R., Bradford, L., Cardinal, K., Carriere, G., Fresque-Baxter, J., Jardine, T. D., MacColl, I., Macmillan, S., Marten, J., Orosz, C., Reed, M. G., Rose, I., Shmon, K., Shantz, S., Staples, K., Strickert, G., \& Voyageur, M. (2018). Identifying transformational space for transdisciplinarity: using art to access the hidden third. Sustainability science. Retrieved from https://link.springer.com/content/pdf/10.1007\%2Fs11625-018-0644-4.pdf

Tate. (2019). Art term: bricolage. Retrieved from https://www.tate.org.uk/art/art-terms/b/bricolage

Timm-Bottos, J., \& Reilly, R. C. (2015). Learning in third spaces: community art studio as storefront university classroom. American Journal of Community Psychology, 55(1-2), 102-114. https://doi.org/10.1007/s10464-014-9688-5 


\title{
KŪRYBINIŲ MENO PRAKTIKŲ TRANSFORMACIJOS GALIMYBĖS TARPDALYKINIŲ TYRIMŲ KONTEKSTE
}

\author{
Kyong-Mi PAEK \\ Santrauka
}

Vis augančiame kiekyje literatūros, kurioje demesys skiriamas švietimo inovacijų poreikiui, taip pat pabréžiama tarpdalykinių metodų, ịtraukiančių meną ị mokymą ir mokymąsi, vertè. Šiame straipsnyje siekiama praplèsti meno ir mokslo sąveikos supratimą, pristatant empirinị tyrimą, kuriame nagrinèjama unikali meno rezidentūros programa, sukurta universiteto, besispecializuojančio mokslo ir technologijų srityje, miestelyje. Tyrime apžvelgiamos trijų šiuolaikinių menininkų, dalyvavusių programoje, sukurtoje kartu su dalykinio tyrimo projektu, meno praktikos, ieškant būdų suformuoti ekologine prasme tvarią bendruomenę, kurią valdytų atsinaujinančios energijos šaltiniais grindžiama ekonomikos sistema. Duomenys, apimantys stebejjimus, menininkų pokalbius ir interviu su asmenimis, buvo surinkti iš daugelio šaltinių, siekiant suprasti atskirus procesus, kuriuos apima individualių meno projektų plètra. Tolesnẻ kryžminė analizė atskleidẻ keletą îsidèmètinų charakteristikų: menas susiejamas su gyvenimu perdirbant atliekas, ị procesą orientuotos praktikos pabrèžia išteklių cirkuliavimą, o vertẻ kuriama pasitelkiant brikoliažo strategijas. Atsižvelgiant ị švietimo reikšmę, diskusijos, kuriose susitelkiama i galimą transformacijos erdvą, išsirutuliojo iš kūrybinių meno praktikų tarpdalykinių tyrimų kontekste.

Reikšminiai žodžiai: meno rezidentūra, šiuolaikiniai menininkai, kūrybinè praktika, švietimo inovacijos, transformacijos erdvè. 